\section{PL-001＼cjkstart比嗡表現の適切性判断に及ぼす主題 一喻辞の共有特徵数の影響}

○岡 隆之介 ${ }^{1}$, 楠見 孝

( ${ }^{1}$ 三菱電機, ${ }^{2}$ 京都大学)

キーワード：比喻, 適切性, 共有特徴

本研究では, 主題一喻辞の共有特徵の数が, 比喻表現の適切性判断に 及ほす影響を検討する。研究 $1 \quad(N=60)$ では, 主題一喻辞の共有特徴数 が 1 つの条件（例：彼女の皮肉は痛い）と，2つの条件（彼女の皮肉は 痛く, 人を傷つける）の場合で, 呈示された比喻（彼女の皮肉は短刀だ） がその特徴を捉えている程度を 7 件法で回答させた。結果， 2 つ条件は 1 つ条件よりも特徴を捉えていると判断された。続く研究 $2(N=168)$ では, 共有特徴が 2 つ条件と, 共有特徵が 1 つと喻辞に固有の特徴が 1 つ条件（彼女の皮肉は痛く, 人を切る）と, 喻辞に固有の特徵が 2 つ条 件（彼女の皮肉は人を切り, 短い) で比較した。結果, 共有特徴数が増 えるにつれて特徵を捉えている程度が高くなった。最後に研究 $3(N=$ 168）では, 共有特徴が 2 つ条件と, 共有特徴が 1 つと主題に固有の特徵 が1つ条件（彼女の皮肉は痛く，嫌味だ） と, 主題に固有の特徴が $2 つ$ 条件（彼女の皮肉は嫌味で, 言われる）で比較した。結果, 共有特徵の 数が増えるにつれて特徵を捉えている程度が高くなった。これらの結果 は, 主題と喻辞の交互作用が比喻の適切性を規定すると考える property attribution model (Gluckserg, et al., 1997) を支持した。

連絡先 E-mail：Qualia1006@gmail.com

注）＃印は日本心理学会会員以外であることを示す。

\section{PL-002}

\section{成人誤信念理解における作業記憶と 類推 ( I ) 一真実の表象抑制と誤信 念内容の強化・写像一}

○光田 基郎

(1)ースアジア大学)

キーワード：作業記憶, 類推, 誤信念理解ふ

（1）学生に画面で読み聞かせた絵本（民話：虎と干柿）の理解における 誤信念理解で, 真実を抑制した誤信念内容の受容と作業記憶過程の類推・ 写像操作を指摘した。(2)絵本の理解技能として, 内容の推理・逐語再認, 統語, 反応抑制, 図形での類推及び絵本とは無関係の文に描かれたエピ ソードの順序想起 (長文理解) の他, 誤信念課題では通常のサリーアン 型 2 肢選択課題以外に 4 肢選択課題では, (イ) 誤信念課題文の主人公が 最初に対象を格納した青色容器，（口）その後に別人が無断で対象を移し 替えて容器の配置も変えたため, 主人公には予期し得ない移動先である 赤色容器, (八) 無效情報の紫容器と(二) 緑容器の各々を主人公が選択す る確率の主観的評定值を得た。(3) 主人公と別人の行動について参加者を 3 等分して上記(口)の別人が赤容器または(ハ)紫容器に移し替えた条件 または (ホ)別人がどの容器に移したか否かは不明条件の 3 群別に判別分 析と重回帰分析で推理再認成績の規定要因を求めた結果，上記(ホ)群だ けはサリーアン課題と抑制が正の説明変数, 類推成績と赤容器の選択確 率が負を示す。 $\rightarrow($ ホ)群以外では言語より視空間表象の操作（流動的知 能）が顕在化する。

連絡先 E-mail：mitsuda@nau.ac.jp

\section{PL-003＼cjkstart聞き手の非肯定的なあいづちは洞察 を促進する}

○紀ノ定保礼

(1静岡理工科大学)

キーワード: 洞察, 問題解決

三宮・山口（2019，心理学研究）によれば，明確な答えのないテーマ に関して議論する際に，聞き手が肯定的なあいづちを打つことが多いと， 中立的または非肯定的なあいづちを打つことが多い場合に比べて，アイ デイアを思いつき発話した数が多かった。

一方で有賀（2013，心理学研究）は，明確な答えが存在するがそれを 思いつきにくい洞察課題において，作業者自身が現在取り組んでいる解 法の失敗に気付きやすくなると, ひらめきが生じやすくなり, 問題解決 に至りやすいことを報告した。

本研究の参加者は 4 分間，有賀（2013）と同一の洞察課題に単独で取 り組んだ後, サクラの参加者と解法に関して議論を 2 分間行った。参加 者が提案する解法に対して, サクラは肯定的・中立的・非肯定的なあい づちを返した (参加者間要因。各群15名)。参加者はその後, 単独で課題 を遂行した (最大 26 分間) 。

サクラが非肯定的なあいづちを返した場合は，肯定的なあいづちを返 した場合に比べて, 制限時間内に解に至った参加者が多かった。解法に 関する議論相手からの非肯定的なあいづちにより, 解のない問題空間か ら解のある問題空間へ移行しやすくなったため, 洞察が促進されたと考 えられる。

\section{PL-004＼cjkstart物語の認知的ジャンルの特徵（1） 一ジャンルタグの収集一}

○福田 由紀 ${ }^{1}$, 望月 正哉, 井関 龍太 ${ }^{3}$, 常深 浩平 ${ }^{4}$, 長田 友紀5, ${ }^{5}$, 石黑 圭6,夰

( ${ }^{1}$ 法政大学, ${ }^{2}$ 日本大学, ${ }^{3}$ 大正大学, ${ }^{4}$ 淑德大学, ${ }^{5}$ 筑波大学, ${ }^{6}$ 国立国語研 究所)

キーワード：物語，認知的ジャンル，ジャンルタグ

文章のジャンルは，専門的知識や文章の形式から分類されることが多 い。教育現場での教材選択には，読者の文章に対する捉え方も重要な判 断材料となるであ万う。われわれはこのような読み手によるジャンルの 捉え方を認知的ジャンルと呼ぶ。本研究では, 教材にも使用されている 物語に対象を限定し, 読者の認知的ジャンルを明らかにするため, 多く の人に共通する説明表現であるジャンルタグを収集した。大学生・大学 院生37名に，読んだことのある物語を人に紹介する際に使う／使えそう な表現を63個のジャンルタグからすべて選ばせた。それらのジャンルタ グは，物語の内容的な側面が反映されるよう広く集められた。また，選 択肢に無い場合は自由記述させた。その結果, 自由記述された表現は 14 個であり, 頻度は各 1 であった。また, 使用されなかった 2 個のジャン ルタグを除き, 選択率の共起頻度に関してW Ward 法による階層的クラス ター分析を行った。選択率の高さとクラスターの代表性の程度を考慮し， 認知的ジャンルを表現するためのタグとして「ミステリ」「文学」などの 15個のジャンルタグを選択した。※なお，本研究はJSPS科研費 JP20H01764 の助成を受けたものです。

連絡先 E-mail：yfukuda@hosei.ac.jp 